\title{
Artists' Pages
}

\section{Simon Ellis}

[The following is a text-based adaptation of the performance-presentation, Watching, presented at OpenSource\{VideoDance\} 2007, Findhorn, Scotland on November 23, 2007.]

Watching

Video (available to stream at http://vimeo.com/11016394)

This video was screened simultaneously with one other video.

Both videos had only one audience member each.

The videos were rear-projected on screens that were $1.5 \mathrm{~m}$ away from their respective viewers.

What lies outside of the frame?

In dance-on-screen writing and thinking there has been an invaluable emphasis on overcoming the problems of framing and screening movement. The language is strong: "the rigid, rectangular window"

(Nagrin 33), "the often-deadening space of the screen"

(Rosenberg 13). ' Within this screen we witness the body's "flattening" (Preston 79). ${ }^{2}$ The screen topples three dimensions into two. This flattening, powered by what André Lepecki calls the "reductive operation of the camera as perspectival machine" (75), has occupied our thinking, acting as a reason to engage with screendance (and a reason to avoid it). ${ }^{3}$

At the heart of this language is an overwhelming concern for what the camera sees, and consequently, what is produced on screen. Doug Rosenberg describes the phenomenon of camera-looking as an act that "implies a reverence for that which is framed and eschews all that is outside the frame" (14-15). However, to (over)emphasize what is within frame (or onscreen) is to run the risk of joining conventional cinema in presupposing the viewing experience. Our shared performance heritage - itself a critical aspect of screendance hybridity-necessitates an acknowledgement that screendance content also lies beyond the frame.

There were also two live performers.

Both audience members watched their "own" performer

(but were able to see the other if they chose to).

But before I talk about aspects of the nature of content, I need to back up a bit. 
In 2000, I was teaching choreography to final year dance students at the Victorian College of the Arts in Melbourne. We were dealing with a rather formalist approach to choreographic ideas, and the question of form-content existing on some kind of continuum was raised. That night I was talking about this with my girlfriend at the time (that's the love story part) — a visual and installation artist called Elizabeth Boyce - who suggested a small book by Thomas McEvilley: Art \& Discontent (1991). Actually, she didn't recommend the book so much as give me an old photocopied handout of a section of the book called Thirteen Ways of Looking at a Blackbird. The book's language is plain, and clear, and is an excellent example of arts theory writing that is inclusive, provocative and evocative. Better still, McEvilley appears to hold no fears in tackling many of the 'givens' in arts theory. That is, to discuss in detail the things we might believe are self-evident (or even obvious), but so easily forget, ignore or avoid. "Every critic should give indication of the sources and limits of his knowledge" (Pound 56). ${ }^{4}$

Some confessions:

This paper is heavily based on McEvilley's writing. I am not suggesting that I am an expert on questions of form and content. Occasionally I read art theory because I feel a little obliged.

Each audience member was located on a viewing platform.

The ambient sound of the live performance (prior to the video performance) was miked and sent to the audience's headphones.

The principle concern for McEvilley in Art and Discontent is to forcefully debunk any notion that works of art_-of any kind — exist in a formal vacuum. In other words, that the formalist dream of excluding non-audiovisual elements from how work is experienced is implausible. To attempt to deprive work of content probably sounds a little bizarre considering our contemporary awareness for the cultural imprinting of how (and what) we watch, but this is what formalists desired. In 1966, Susan Sontag wrote: "It is the habit of approaching works of art in order to interpret them that sustains the fancy that there really is such a thing as the content of a work of art" (11). ${ }^{5}$

But, for McEvilley, such formalist ideals are seriously compromised simply because he wonders how, when viewing works of art, we can ever avoid the "associative habit" (45) of the human mind. ${ }^{6}$ The question becomes not whether content is present, but rather the 
nature of its relationship to form. Here, McEvilley uses semiological terms to clarify the form/content relationship as being either

motivated or unmotivated.

If the relationship is motivated, then content is inherent in the formal properties of the work. If the form-content relationship is unmotivated then content is added to the work by the work's audience - including the artist or artists (McEvilley and Denson 38).?

Each audience member had a pillow under the head.

Each audience member wore high quality headphones.

It was all very comfortable.

The distinction is more subtle than it first appears. Many things that are "outside" of a work can easily_ and intuitively_be placed within it. Examples might be the reputation of the artist, her record of earlier work, or even the assumption that an artist has seen a certain work (McEvilley and Denson 37-8).

"What is content, anyway? And, are we involved?" (McEvilley 69)

In this paper I am going to consider some aspects of content in dance on screen that are typically (and easily) forgotten as being content. These are derived from a selection of McEvilley's Thirteen Ways of Looking at a Blackbird (70), and are: content added to a work over time; content arising from the genre or medium of an artwork; and content arising from context.

Before the videos were played, audience members watched their "own" performers live. This performer was also the "subject" of that audience member's video.

Content added to a work over time

"Whatever occurs to a work as its history unfolds becomes part of the experience of the work, and part of its meaning, for later generations" (McEvilley 79).

An example of this is the German-born, Australian-based choreographer and dancer, Tanya Liedtke, who died tragically in Sydney in August 2007. The 30 year old, known in the UK for her work (in particular) with DV8, was about to take over the artistic direction of Sydney Dance Company_an extraordinary challenge, and one she clearly was excited about. Content is accrued to her work as its "destiny" is added to through time. Tanya's work becomes the work of "the emerging choreographer whose life ended tragically at age 30." In effect, and I mean this with sensitivity and a certain amount of sadness, her death has added to the content of the work 
she has made, and impacts on how it is experienced and viewed as it continues to be presented around the world.

A more banal (and less terrible) example might be a screendance work that is re-edited some years after its first cut. In much the same way as Ridley Scott has treated us to various versions of

Blade Runner (1982), it is not so much that footage (or voiceover) has been added to or removed, but that a reedit has occurred that contributes to and becomes part of the meaning of the work through time. Of course, the edits also shift the content of the work—but that goes without saying.

Content arising from the genre or medium of the artwork

Implicit in the notion that genre adds content to an artwork is the categorization of artworks as existing within particular genres (and not others). Such categorization invariably leads to questions about popular versus elitist works of art. In screendance, this, perhaps, is evident in the rather fraught relationship that contemporary dance practices have with music videos.

I am currently editing a project called Tuesday that could, in effect, be described as a music video. Recently I was working on an application for a festival and read the following guidelines: "Illustrative or interpretive work, (e.g. music videos), will not be suitable" (Threshold). ${ }^{8}$

Is this what I am doing? Illustrating a song? Indeed, is this all that music videos do-illustrate or interpret songs? Don't some genres of dance performance do precisely this? Is this bad? Are there rules?

How do I get a copy of the rulebook?

When asked, "What is taste?" Marcel Duchamp replied "habit."

Spike Jonze's work is wonderfully unsettling in this respect. His video work in the late 1990s with the fictitious Torrance Community Dance Group simultaneously parodied modern dance and dance video clips. And in How They Got There (1997) ${ }^{9}$ Jonze creates what might be described as a familiar screendance scenario, including a delightful little ditty between two dancing strangers, only to have the 3-minute

film end in a massive out-of-nowhere car crash sequence.

In order to watch the videos, both platforms were manually rotated from vertical until they were almost horizontal.

And what about questions of format? To shoot on film unquestionably adds content to a project. But then, so too does shooting on my camera phone. Another example of genre adding content to artwork might be a screendance director deciding to return to a single fixed camera setup 
filming live performances in a proscenium-arch theatre. Considering screendance's origins in documenting live performance, for a choreographer/director to work this way adds political and cultural significance and content to the project, and the screendance field more generally.

Content arising from the context of the work

Katrina McPherson's DVD_Five video dances $(2006)^{10}$ exemplifies this idea. Billed as a companion to her book Making Video Dance (2006), "1he DVD effectively "bundles" these five works together, encourages them to be viewed together, and compared with one another.

But, perhaps more importantly, by connecting the DVD with the book, the works take on pedagogical content: Tools for the aspiring screendance artist to watch, learn, and even imitate.

The five video dances are no longer the same works when first presented: not only has the physical format of their presentation been altered, but they have taken on alternate contexts and are now reframed as essential undergraduate screendance viewing.

The presence of screens above the audience (as they were tilted backwards)

was a surprise to them.

Whilst the videos were playing, the two performers remained active

in the (peripheral) performance space.

As a Physical Education undergraduate in the late 1980s, when

Bobby McFerrin sang Don't Worry, Be Happy and U2 was still reasonably cool, our most feared Professor would occasionally, at the conclusion of a student oral presentation, lean back in his chair, stroke his cleanly shaven chin, and ask that most dreaded of all questions: So what?

To remember, to examine, and to consider how content is developed and accumulated in the construction, presentation and watching of screendance, invites newness.

"By foregrounding an element of content usually taken for granted and invisible, a whole new artistic mode or direction can be discovered" (McEvilley 187-88).

At the end of the video(s) the platforms were (slowly) tilted back to vertical.

This experience of being tilted (very slowly) had a major impact on the watching.

One audience member commented: "At the end I felt I had passed through

something, and had a strong sense that something had been done to me." 
If one of the current concerns in screendance research and thinking is

to articulate the medium and form clearly, then in this paper I have been interested in broadening and roughening the edgesin threading movement (or uncertainty) into our critical engagement with the form-and in questioning the in/stability of the screendance viewing process in the emergence and development of content. Actually, there's one other of McEvilley's thirteen ways of looking at a blackbird that is perhaps worth considering:

Content arising from verbal supplements supplied by the artist

McEvilley quotes Edward Said, and although Said is talking about literary texts, I have transposed this word with a more general term: "art works."

"[Art works] impose constraints and limits upon their interpretation ... because as artworks they place themselves. . . they are themselves by acting, in the world. Moreover, their manner of doing this is to place restraints upon what can be done with (and to) them interpretively" (Edward Said, cited in McEvilley 48). To add content, to constrain the interpretive process. The most blatant example of "verbal supplementation" is the title given to a work by an artist.

The project's title is Inert (Ellis, Corbet et al. 2006). ${ }^{12}$

www.skellis.net/Inert.

\section{Notes}

1. Nagrin, Daniel. "Nine Points on Making your Own Dance Video." Dance Theatre Journal 6.1 (1988): 33-36. Print; Rosenberg, Douglas."Proposing a Theory of Screendance." Screendance: The State of the Art. American Dance Festival. Duke University, Durham, NC. July 6-9, 2006. Talk.

2. Preston, Hilary. "Choreographing the frame: a critical investigation into how dance for the camera extends the conceptual and artistic boundaries of dance." Research in Dance Education 7.1 (2006): 75-87. Print.

3. Lepecki, André. Exhausting Dance: Performance and the Politics of Movement. London: Routledge, 2006. Print.

4. Pound, Ezra. Literary Essays of Ezra Pound. Ed. T. S. Eliot. New York: New Directions, 1968. Print.

5. Sontag, Susan. Against Interpretation. New York: Vintage, 1994. Print.

6. McEvilley, Thomas. Art \& Discontent: Theory at the Millennium. New York: McPherson \& Company Publishers, 1991. Print.

7. McEvilley, Thomas and G. Roger Denson. Capacity: History, the World, and the Self in Contemporary Art and Criticism. London: Routledge, 1996. Print.

8. Threshold Studios. Critical Mass: Hypnos. Northampton, UK, 2007. Videoproduction commissioning proposal.

9. Jonze, Spike. How they got there. USA: Palm Pictures, 1997.3 minutes. Video.

10. McPherson, K. Five Video Dances. Goat Media Ltd., 2006. Video.

11. --. Making video dance: a step-by-step guide to creating dance for the screen. London, Routledge, 2006.

12. Ellis, S., D. Corbet, et al. Inert. Melbourne: Dancehouse, 2006. 